\title{
Maximizing Radiologist Productivity: The Panopticon
}

\author{
Richard B. Gunderman, MD
}

Benjamin R. Gray, MD

Satire, by being levelled at all, is never resented as an offense by any.

—Jonathan Swift

Though almost completely unheralded in radiology, one of the most prophetic explorations of workplace supervision was provided by the French historian Michel Foucault. Ostensibly a sociological history, Foucault's masterpiece outlines a path that radiology leaders must be prepared to follow if they intend to extract full value from their workers, in particular their clinical radiologists. Foucault's work, titled Discipline and Punish: The Birth of the Prison, traces out a trajectory that all radiology organizations will someday be compelled to follow.

Foucault [1] begins his analysis with a discussion of 17th-century punishments, focusing on the scaffold and other public forms of humiliation, torture, and execution. At this time, punishment took place on a public stage and was focused on the infliction of physical discomfort and pain. Later, punishment began to evolve in a different direction, placing greater emphasis on the isolation of prisoners and moving toward noncorporeal techniques, including restrictions on liberty through confinement [2]. Perhaps the fullest expression of this more enlightened approach is solitary confinement.

This is the author's manuscript of the article published in final edited form as:

Gunderman, R. B., \& Gray, B. R. (2016). Maximizing Radiologist Productivity: The Panopticon. Journal of the American College of Radiology, 13(2), 173-174. http://doi.org/10.1016/j.jacr.2015.10.012 
This transition in punishment included the introduction of the panopticon, a new form of imprisonment proposed by Jeremy Bentham, the founder of utilitarianism. Born in London in 1748, Bentham was a philosopher and social reformer who argued that the measure of right and wrong is "the greatest happiness of the greatest number" [3]. Bentham spent 16 years developing the panopticon, which he hoped would be adopted as the plan for a national penitentiary at which he hoped to serve as both contractor and governor.

Bentham saw his new invention as the perfect architectural model for a disciplinary institution [4]. It consisted of a ring-shaped, multilevel layout of cells, each with a window on both its inner and outer walls [5]. In the center of the ring sat a supervisor in a tower who, though invisible to the inmates, could see each of them [5]. The panopticon was designed to make inmates feel that they were under constant surveillance, eliminating any hope that they could carry out plots in secret [4]. One of the things Bentham liked most about the panopticon was its efficiency, enabling a few guards to control many inmates [5].

Foucault saw the panopticon as a model to be used any time a supervisor needs to ensure that many individuals conform to a specified pattern of behavior. The same systems used to monitor prison inmates could also be used "to instruct schoolchildren, confine the insane, supervise workers, and put beggars and idlers to work" [4]. Though in many respects prescient, however, even Foucault failed to recognize the full potential of the panopticon in the workplace, where it offered truly remarkable possibilities for monitoring and reproving idle workers.

Many radiologists and radiology organizations are operating at less than peak capacity, employing workers who are not productive $100 \%$ of the time. To rectify this regrettable situation, leaders need to develop a better means of monitoring worker output and intervening 
whenever a worker is not producing at full potential. Bentham and Foucault merely hinted at the perfect remedy. In a perfect world, radiologists, like inmates in a prison, would be made to feel that their work is under constant scrutiny and that any lapses in output will be promptly detected and punished.

Thanks to 21st-century surveillance and productivity-monitoring technology, this dream can at last be fully realized. New innovations in hardware and software make it possible to monitor radiologist output not only quarterly but day to day and even hour to hour. A welldesigned radiology information system makes it possible to provide a dashboard on each radiologist, comparing current productivity with that of colleagues, as well as with each's own past performance. When relative value units per hour dip below a certain threshold, alarms can be triggered automatically.

And such surveillance need not stop with the rate at which reports are generated. By using cameras in the reading room, it is possible to detect when a radiologist has stepped away from the workstation, surfed the web, dozed off, or simply become distracted. In accordance with the panopticon model, the supervisor responsible for such monitoring can be stationed at a remote location, keeping tabs on numerous radiologists simultaneously. In fact, thanks to modern artificial intelligence, the supervisor need not even be human.

Performance can be tied directly to rewards and punishments. For example, a radiologist who manages to maintain the desired level of productivity with no lapses might receive full compensation. On the other hand, a portion of full compensation can be withheld from radiologists who fail to meet targets, whereas radiologists who consistently exceed expectations 
can receive bonuses. Of course, clinical productivity need not be the sole criterion. Productivity might also include number of minutes spent teaching, or number of conferences attended.

And just as the design of the panopticon prevented potentially dangerous fraternization among inmates, so the radiology panopticon will prevent idle chitchat and other wasteful forms of interaction among radiologists. For example, workers could be sequestered in different rooms, in different sections of a building, or at different off-site locations. Likewise, they could be shielded from interruptions by making them inaccessible to referring physicians and other health professionals who might distract them from the task at hand.

As in Bentham’s model, radiology “inmates” would not know whether they were being observed at any particular moment, yet they would live with the awareness that surveillance was ever present. To borrow a phrase from Orwell's 1984, it would seem to them as if Big Brother were constantly watching [6]. To fan the flames of surveillance anxiety, and thus undergird a maximal level of control over behavior, workers should be kept in the dark regarding the identities of their supervisors. They should not know whether they are being watched by a personal acquaintance or a surveillance specialist.

As Foucault [4] put it, the inmate, or in this case the radiologist, should always be "the object of information, but never a subject in communication.” The only feedback radiologists should receive, and always from a source whose identity is kept as obscure as possible, is whether they are meeting their productivity targets. All feedback might be provided through dialog boxes on their workstations. Every radiologist should be made to feel that he or she is listened to but not heard, observed but not attended to, and valued strictly as a means of production and never as a source of insight. 
One of the surest ways to undo the many advantages of the panopticon is to allow any semblance of humanity or personal concern to leech into the system. The model works precisely because it is a machine, devoid of all human relationship. Though the inmates, or in this case, radiologists, are in fact human beings, the panopticon acknowledges this fact to the slightest possible extent. If workers begin to feel that their perspective might, from the standpoint of the supervisors, count for something, many of the advantages of the panopticon inevitably begin to erode away.

Though it is admittedly anachronistic to say, there was once a time when a simpler system might have sufficed. In the dark ages, jailors might simply have placed radiologists in dungeons and chained them to workstations. Stationed behind each could be a keeper with a whip or other instrument of punishment. Despite its obvious attractions, such a system simply would not do today. For one thing, today’s labor costs render a one-to-one guard-to-radiologist ratio economically prohibitive. Furthermore, industry watchdogs would never permit the installation of dungeons in health care facilities.

Thanks to Bentham and Foucault, however, we have at last reached a historical juncture at which every wasted ounce of energy and every misspent minute can be purged from the system. Where work ethic, a shared sense of mission, and mutual respect were once the only guarantors of productivity on which many radiology practices could rely, effectively offering every slacker a "get out of jail free” card, 21st-century technology is finally providing a much more powerful means of ensuring that all radiologists work as hard as they possibly can all of the time. 


\section{References}

1. Foucault M. Part 1: torture. In: Sheridan A, trans. Discipline and punish: the birth of the prison. New York: Vintage; 1995:32-69.

2. Foucault M. Part 4: prison. In: Sheridan A, trans. Discipline and punish: the birth of the prison. New York: Vintage; 1995:231-308.

3. Bentham J. The works of Jeremy Bentham, published under the superintendence of his executor, John Bowring, Vol. 10, William Tait, Edinburgh, United Kingdom (1843) Available at: http://galenet.galegroup.com/servlet/MOML?af=RN\&ae=F3700669450\&srchtp=a\&ste=14 Accessed September 27, 2015

4. Foucault M. Part 3: discipline. In: Sheridan A, trans. Discipline and punish: the birth of the prison. New York: Vintage; 1995:135-228.

5. Bentham J. The panopticon writings. Bozovic M, ed. London: Verso; 1995.

6. Orwell G. 1984. New York: Signet Classic; 1950. 